\title{
Effect of somatotropin administration and duodenal infusion of methionine and lysine on lactational performance and nutrient flow to the small intestine
}

\author{
BY J. M. ALDRICH* L. D. MULLER† AND G. A. VARGA \\ Department of Dairy and Animal Science, The Pennsylvania State University, University Park, \\ $P A$ 16802, USA
}

(Received 8 May 1991-Accepted 21 January 1992)

\begin{abstract}
Lack of sufficient methionine and lysine delivered post-ruminally may limit milk production response to bovine somatotropin (bST). To test this hypothesis, four Holstein cows fitted with rumen and duodenal cannulas were used in a $4 \times 4$ Latin square design with $14 \mathrm{~d}$ periods. Treatments were: (1) control, (2) continuous duodenal infusion of $8 \mathrm{~g}$ methionine and $24 \mathrm{~g}$ lysine/d, (3) injection of $25 \mathrm{mg} \mathrm{bST} / \mathrm{d}$ and (4) infusion of methionine and lysine plus injection of bST. Infusion of amino acids led to trends for small increases in milk (3\%), fat (5.5\%), and protein (3.7\%) yield. Larger and significant increases $(8.7,14$ and $6.9 \%$ for milk, fat and protein yield respectively) were achieved with bST administration which also increased milk fat content. Plasma levels of urea- $\mathbf{N}$ and essential amino acids were reduced with bST. Duodenal nutrient flow was generally unaffected by treatment. The production response to bST was not enhanced in cows producing an average of $34 \mathrm{~kg}$ milk when provided additional methionine and lysine post-ruminally in this short-term study.
\end{abstract}

Methionine: Lysine: Somatotropin: Nutrient flow

The effect of bovine somatotropin (bST) on stimulating consistent increases in milk production is well documented and has been reviewed by others (Bauman \& McCutcheon, 1986; Peel \& Bauman 1987). The enhanced milk production occurs within a few days of the onset of bST administration, but there is a lag of several weeks before feed intake increases (Bauman et al. 1985) and, in short-term studies, no change in intake has been observed for cows treated with bST (Peel \& Bauman, 1987). This rapid increase in milk yield in relation to a delayed response in intake suggests that the nutrient density of the diet may need to be increased. The increased energy secretion in milk when cows are treated with bST occurs at the expense of tissue energy retention (Tyrrell et al. 1988). Although labile protein reserves may be substantial (Botts et al. 1979), they can be rapidly depleted in early lactation and, thus, the sufficiency of amino acids from body stores may be inadequate to meet the demands of higher milk production when cows are treated with bST (Peel et al. 1981). When cows were in negative $\mathrm{N}$ balance, they tended to become more negative when treated with bST and the increase in yield of milk protein was less than the increase in milk yield (Tyrrell et al. 1988). Cows fed on protein-deficient diets (110 g/kg dry matter (DM)) responded with a smaller increase in milk production when treated with bST than did bSTtreated cows fed on protein-adequate diets $(160 \mathrm{~g} / \mathrm{kg} \mathrm{DM})$. Treatment with bST had no

\footnotetext{
* Present address: Carl S. Akey Inc. Lewisburg, OH 45338, USA.

$\dagger$ For reprints.
} 
effect on $\mathrm{N}$ retention for either dietary treatment (De Boer \& Kennelly, 1989a). These findings suggest that diets marginal or deficient in protein or amino acids may limit the milk yield or milk-protein yield response to bST.

Few other studies have examined the effect of manipulating dietary protein for bSTtreated cows. Milk yield response was enhanced $1.6-1.8 \mathrm{~kg} / \mathrm{d}$ by increasing the undegradable protein (UP) from 330 to $400 \mathrm{~g} / \mathrm{kg}$ total protein (McGuffy et al. 1990); however, increasing UP from 360 to $400 \mathrm{~g} / \mathrm{kg}$ total protein as well as increasing the dietary fat level did not increase milk yield of bST-treated cows (Lormore et al. 1990). Winsryg et al. (1991) observed no increase in milk yield when the dietary UP was increased for cows treated with bST; however, milk protein and casein contents were elevated for cows fed on the high-UP diet. Supplementation of an $180 \mathrm{~g}$ crude protein $(\mathrm{CP} ; \mathrm{N} \times 6.25) / \mathrm{kg}$ diet with abomasal infusion of casein and glucose did not increase milk yield beyond that achieved by bST alone (Peel et al. 1982).

Recent interest has focused on the quantity of amino acids flowing to the small intestine (Schwab, 1989). Lysine and methionine are the two essential amino acids (EAA) that are most probably limiting for high milk production (Schwab, 1989) and may be more limiting for cows treated with bST.

The objectives of the present experiment were to determine whether the short-term milk production response to bST could be enhanced by providing supplemental methionine and lysine post-ruminally and to measure duodenal nutrient flow and plasma amino acid and urea-N levels of cows treated with bST.

\section{MATERIALS AND METHODS}

\section{Animal management and experimental design}

Four 2nd lactation Holstein cows, 61 (SD 11) d in milk at the onset of the trial, were used. Cows were fitted with rumen and duodenal cannulas. The latter was a ' $Y$ ' plastisol cannula with a $25 \mathrm{~mm}$ inside diameter and an $135^{\circ}$ internal flange angle and was placed anterior to the bile ampulla. Cows were housed in individual tie stalls and milked twice daily at 06.00 and 17.00 hours.

The experimental design was a $4 \times 4$ Latin square. Treatments were (on a daily basis): (1) control (C): 41 tap water infused into the duodenum and an intramuscular injection of $5 \mathrm{ml}$ buffered saline ( 9 g sodium chloride/1); (2) amino acid infusion (AA): $8 \mathrm{~g}$ DL-methionine and $24 \mathrm{~g}$ L-lysine hydrochloride (US Biochemical Corp., Cleveland, $\mathrm{OH}$ ) in 41 tap water infused into the duodenum; (3) bST injection (bST): intramuscular injection of $25 \mathrm{mg}$ bST (Lilly Research Laboratories, Greenfield, IN) in $5 \mathrm{ml}$ buffered saline; (4) combination $(\mathrm{AA}+\mathrm{bST})$ : infusion of amino acids plus injection of bST.

The amino acid solution or water alone was infused continuously via a peristaltic pump (model no. 7520-25, Cole Parmer Inc., Chicago, IL) fitted with four pump heads. Bottles (51) of amino acid solution were prepared daily with the pump set to deliver $41 / \mathrm{d}$. Bottles were changed at approximately $24 \mathrm{~h}$ intervals and the amount remaining was measured to monitor the amount infused. The bST was prepared daily by dissolving $25 \mathrm{mg}$ active material into $5 \mathrm{ml}$ of a buffered saline solution and gently agitating at $39^{\circ}$ for $15 \mathrm{~min}$ before injection.

Experimental periods were $14 \mathrm{~d}$. Cows were fed twice daily at 06.00 and 16.30 hours. The diet consisted of ( $\mathrm{g} / \mathrm{kg}$ DM basis) : maize silage 49 , chopped grass hay 7 , concentrate 44 (Table 1). Feeds were mixed at each feeding and the amount offered was intended to achieve a $10 \%$ refusal. Feed intake was recorded during the last $4 \mathrm{~d}$ of each period and daily samples of maize silage, grain mix and refusals were obtained and composited at the end of each period. 
Table 1. Ingredients and chemical composition of diet $(\mathrm{g} / \mathrm{kg} \mathrm{DM})$

\begin{tabular}{lr}
\hline Ingredients & \\
Maize silage & $494 \cdot 0$ \\
Grass hay & $70 \cdot 0$ \\
Shelled maize & $214 \cdot 0$ \\
Soya-bean meal & $144 \cdot 0$ \\
Maize-gluten meal & $18 \cdot 0$ \\
Calcium salts of long-chain fatty acids & $18 \cdot 0$ \\
Molasses & $15 \cdot 0$ \\
Dicalcium phosphate & $5 \cdot 5$ \\
Sodium bicarbonate & $5 \cdot 0$ \\
Salt & $4 \cdot 0$ \\
Dynamate* & $3 \cdot 5$ \\
Calcium carbonate & $3 \cdot 1$ \\
Trace mineral and vitamin premix $\dagger$ & $2 \cdot 5$ \\
Urea & $2 \cdot 1$ \\
Magnesium oxide & $1 \cdot 3$ \\
Chemical composition & \\
Crude protein (nitrogen $\times 6 \cdot 25)$ & 168 \\
Degradable protein $\ddagger$ & 111 \\
Undegradable protein $\ddagger$ & 57 \\
ADF & 161 \\
NDF & 302 \\
Ca & 7 \\
P & 5 \\
Mg & 3 \\
K & 10 \\
\hline
\end{tabular}

DM, dry matter; $A D F$, acid-detergent fibre; NDF, neutral-detergent fibre.

* Contained $(\mathrm{g} / \mathrm{kg})$ : Mg 110, S 220, K 180.

$\uparrow$ Contained $(\mathrm{mg} / \mathrm{kg}): \mathrm{Ca} 59 \cdot 6 \mathrm{~g}, \mathrm{Cu} 1250$, Fe 6249, Mn 3124, Se 93, Zn 12500, vitamin A $315000 \mathrm{Iu}$, vitamin D $158000 \mathrm{Iu}$, vitamin E $1400 \mathrm{Iu}$.

$\ddagger$ Estimated from National Research Council (1985).

\section{Data collection and sample preparation}

Milk production was recorded during the last $7 \mathrm{~d}$ and a sample from each morning and afternoon milking was analysed for fat and protein using a Foss 605B Milko-Scan (Foss Electric, Hillerod, Denmark) at the Pennsylvania DHIA Milk Testing Laboratory. A second sample from each milking was composited at the end of each period in proportion to volume, and was frozen $\left(-20^{\circ}\right)$ for subsequent analysis of casein and fatty acid composition.

Duodenal digesta was collected every $3 \mathrm{~h}$ during the last $3 \mathrm{~d}$ of each period and the sampling time was advanced $1 \mathrm{~h}$ daily so that each hour in a $24 \mathrm{~h}$ period was represented. The $\mathrm{pH}$ was measured immediately by glass electrode and $200 \mathrm{ml}$ were added to a common container for each cow and frozen $\left(-20^{\circ}\right)$.

Rumen samples from the dorsal, ventral and anterior regions for bacterial isolation (Varga et al. 1988) were collected at 0,4 , and $10 \mathrm{~h}$ after morning feeding on each of the last $3 \mathrm{~d}$ of the period. Bacterial isolates were lyophilized before analysis for $\mathrm{N}$ and purines. The $\mathrm{N}$ : purine ratio was used to calculate the flow of bacterial $\mathrm{N}$ to the small intestine (Zinn \& Owens, 1986).

Digesta flow was determined using Yb-marked insoluble DM (Glenn et al. 1989). The marker was given intraruminally at 06.00 and 16.30 hours on days $4-14$ of each period ( $240 \mathrm{~g}$ insoluble DM/d). Measured Yb concentration was $8.3 \mathrm{mg} / \mathrm{g}$ insoluble DM.

Blood was drawn from the tail vein or artery into heparinized tubes $3 \mathrm{~h}$ after the morning 
feeding on days 13 and 14 , centrifuged at $3000 \mathrm{~g}$ for $15 \mathrm{~min}$ and the resulting plasma was frozen for urea- $\mathrm{N}$ analysis. For amino acid analysis, $2 \mathrm{ml}$ plasma were added to a centrifuge tube containing $0.2 \mathrm{ml}$ sulphosalicylic acid $(5 \mathrm{~g} / \mathrm{l})$ and centrifuged at $4000 \mathrm{~g}$ for $15 \mathrm{~min}$ and $1 \mathrm{ml}$ plasma was withdrawn and frozen.

\section{Analytical procedures}

Feed and refusals were prepared for analyses by drying at $55^{\circ}$ for $48 \mathrm{~h}$ and grinding through a Wiley mill (1 mm screen) and analysed for crude protein (CP) and ash (Association of Official Analytical Chemists 1980), acid-detergent fibre (ADF) and neutral-detergent fibre (NDF) (Robertson \& Van Soest, 1981). Mineral analyses of maize silage and grain mix were conducted by Skyview Laboratories Inc., Jennerstown, PA.

Duodenal digesta was thawed at room temperature and a portion was withdrawn while the digesta was being agitated with a mechanical stirrer. This sample was used to determine $\mathrm{NH}_{3}-\mathrm{N}$ (Chaney \& Marbach, 1962). Digesta was immediately re-frozen and approximately 11 was lyophilized, ground in a Wiley mill $(1 \mathrm{~mm}$ screen) and analysed for purines, CP, amino acids and $\mathrm{Yb}$ concentration (Hart \& Polan, 1984).

For amino acid analysis of duodenal samples, $150 \mathrm{mg}$ were hydrolysed with $6 \mathrm{M}-\mathrm{HCl}$ (gassed with $\mathrm{N}_{2}$ for $15 \mathrm{~min}$ ) at $110^{\circ}$ for $22 \mathrm{~h}$ in sealed tubes. Hydrolysates were allowed to cool and passed through a $0.45 \mu \mathrm{m}$ pore filter (Millipore Corp., Bedford, MA) and filtrates were diluted with sodium citrate buffer (pH 2.2). Analysis was done on a Beckman 119CL amino acid analyzer (Beckman Instrument Inc., San Ramon, CA).

Plasma urea-N was determined using the Technicon AutoAnalyzer (Technicon Corp., Tarrytown, NY). Analysis of plasma for free amino acids was with a Biotronik LC 5000 amino acid analyzer (Biotronik, Strasse, FRG). Plasma growth hormone $(\mathrm{GH})$ analysis was by the method described by Donkin et al. (1989), except antisera were provided by R.S. Kensinger (The Pennsylvania State University, University Park, PA).

Casein proteins were separated by polyacrylamide gel electrophoresis ( $\mathrm{Ng}$-Kwai-Hang \& Kroeker, 1984). Extraction of milk fatty acids was according to the double-extraction technique of Christopherson \& Glass (1969), the methyl esters were separated on a gas-liquid chromatograph (Perkin-Elmer 8410; Perkin-Elmer Corp., Norwalk, CT).

\section{Statistical analysis}

Data were analysed as a $4 \times 4$ Latin square using the ANOVA procedure of SAS Institute Inc. (1985) with cow, period and treatment as the effects in the model. The sum of squares for treatment was partitioned into single df orthogonal contrasts to determine the effect of amino acid infusion, bST injection, and amino acid $\times$ bST interactions.

\section{RESULTS}

Feed composition

Ingredient and chemical composition of the diet are listed in Table 1. The diet was formulated to meet National Research Council (1989) requirements for cows milking $40 \mathrm{~kg}$ milk. The ADF level was lower than anticipated primarily due to a lower ADF content in the grain and hay mixture than was initially calculated from the ingredients. Estimated degradability of protein (National Research Council, 1985) was 0.66.

\section{Milk production, composition and DM intake}

Treatment with bST increased $(P=0-01)$ milk yield $8 \cdot 7 \%$ (Table 2 ). Fat-corrected milk (FCM), and yield of fat and protein were also increased with bST (Table 2). Amino acid infusion tended to increase milk yield $(P=0 \cdot 11)$, FCM $(P=0 \cdot 12)$, and the yield of fat 
Table 2. Milk production, composition and dry matter intake by cows given control $(C)$, duodenal infusion of methionine and lysine $(A A)$, injection of bST $(b S T)$, or the combination of $A A+b S T \dagger$

\begin{tabular}{|c|c|c|c|c|c|c|c|}
\hline \multirow[b]{2}{*}{ Treatment ... } & \multirow[b]{2}{*}{$\mathrm{C}$} & \multirow[b]{2}{*}{ AA } & \multirow[b]{2}{*}{ bST } & \multirow[b]{2}{*}{$\mathrm{AA}+\mathrm{bST}$} & \multirow[b]{2}{*}{$\mathrm{SE}$} & \multicolumn{2}{|c|}{$\begin{array}{l}\text { Statistical significance } \\
(P=) \text { of effect of* }\end{array}$} \\
\hline & & & & & & AA & $\mathrm{bST}$ \\
\hline Milk $(\mathrm{kg} / \mathrm{d})$ & $31 \cdot 5$ & $32 \cdot 8$ & $34 \cdot 6$ & $35 \cdot 3$ & 0.53 & 0.11 & 0.002 \\
\hline $4 \%$ Fat-corrected milk $(\mathrm{kg} / \mathrm{d})$ & $30 \cdot 4$ & $31 \cdot 5$ & $34 \cdot 0$ & 35.9 & 0.84 & $0 \cdot 12$ & 0.003 \\
\hline Fat: $\mathrm{g} / \mathrm{kg}$ & $37 \cdot 9$ & $37 \cdot 5$ & $38 \cdot 5$ & $40 \cdot 5$ & 0.99 & NS & $0 \cdot 11$ \\
\hline $\mathrm{kg} / \mathrm{d}$ & $1 \cdot 19$ & $1 \cdot 23$ & $1 \cdot 33$ & $1 \cdot 43$ & $0 \cdot 04$ & $0 \cdot 12$ & 0.005 \\
\hline Protein: $\mathrm{g} / \mathrm{kg}$ & $29 \cdot 3$ & $29 \cdot 6$ & $28 \cdot 7$ & $29 \cdot 1$ & $0 \cdot 30$ & NS & NS \\
\hline $\mathrm{kg} / \mathrm{d}$ & 0.92 & 0.96 & 0.99 & $1 \cdot 02$ & 0.02 & $0 \cdot 15$ & 0.03 \\
\hline Dry matter intake $(\mathrm{kg} / \mathrm{d})$ & $20 \cdot 0$ & $19 \cdot 8$ & $19 \cdot 5$ & $20 \cdot 6$ & 0.59 & NS & NS \\
\hline
\end{tabular}

NS, not significant $(P<0-15)$.

* The interaction between AA and bST was not significant $(P>0 \cdot 15)$.

$\dagger$ For details of treatments and procedures, see pp. 50-52.

Table 3. Casein content of milk from cows given control $(C)$, duodenal infusion of methionine and lysine $(A A)$, injection of $b S T(b S T)$, or the combination of $A A+b S T^{* \dagger}$

\begin{tabular}{|c|c|c|c|c|c|}
\hline Treatment... & $\mathrm{C}$ & AA & $\mathrm{bST}$ & $\mathrm{AA}+\mathrm{bST}$ & $\mathrm{SE}$ \\
\hline Casein ( $\mathrm{g} / \mathrm{kg}$ total protein) & 786 & 771 & 776 & 779 & $11 \cdot 6$ \\
\hline \multicolumn{6}{|l|}{ Casein fractions ( $\mathrm{g} / \mathrm{kg}$ casein) } \\
\hline$\alpha$-Casein & 558 & 539 & 579 & 563 & $13 \cdot 1$ \\
\hline$\beta$-Casein & 336 & 353 & 321 & 327 & $12 \cdot 6$ \\
\hline K-Casein & 100 & 101 & 94 & 101 & $3 \cdot 6$ \\
\hline Г2-Casein & $6 \cdot 7$ & $7 \cdot 3$ & $5 \cdot 8$ & $9 \cdot 0$ & $1 \cdot 4$ \\
\hline
\end{tabular}

* Treatment contrasts were not significant $(P>0 \cdot 15)$.

$\uparrow$ For details of treatments and procedures, see pp. 50-52.

$(P=0 \cdot 15)$, and protein $(P=0 \cdot 15)$. However, fat and protein content were not affected by AA $(P>0.15)$. The AA + bST treatment did not increase milk yield or composition above that of $\mathrm{bST}$ alone.

Injection of bST increased the proportion of long-chain fatty acids $(28.8 v .22 .6$; $P=0.05$, and decreased the proportion of short-chain fatty acids $(24.5 v .32 .8 ; P=0.04)$ in milk. AA had no effect on the fatty acid composition of milk.

Casein relative to total protein or casein fractions (Table 3) were not affected by treatment.

Intake of DM averaged $20 \cdot 0 \mathrm{~kg} / \mathrm{d}$ and was similar across all treatments.

\section{Duodenal nutrient flow}

Generally, there was no effect of either bST administration or duodenal infusion of amino acids on flow of nutrients to the small intestine (Table 4). Glycine flow (values not shown) was increased with bST $(181 v .157 \mathrm{~g} / \mathrm{d} ; P=0.04)$. Glycocholic acid present in bile may make a significant contribution to glycine flow (Wanderley et al. 1988) but this would imply increased contamination of samples from biliary secretions in bST-treated cows. However, duodenal $\mathrm{pH}$ was 2.88 for bST-treated cows and 2.82 for controls, indicating that samples 
Table 4. Duodenal flows $(\mathrm{g} / \mathrm{d})$ for cows given control $(C)$, duodenal infusion of methionine and lysine $(A A)$, injection of bST (bST), or the combination of $A A+b S T \dagger$

\begin{tabular}{|c|c|c|c|c|c|c|c|}
\hline \multirow[b]{2}{*}{ Treatment... } & \multirow[b]{2}{*}{$\mathrm{C}$} & \multirow[b]{2}{*}{ AA } & \multirow[b]{2}{*}{ bST } & \multirow[b]{2}{*}{$\mathrm{AA}+\mathrm{bST}$} & \multirow[b]{2}{*}{$\mathrm{SE}$} & \multicolumn{2}{|c|}{$\begin{array}{l}\text { Statistical significance } \\
(P=) \text { of effect of*: }\end{array}$} \\
\hline & & & & & & AA & $\mathrm{bST}$ \\
\hline \multicolumn{8}{|l|}{ Duodenal flow } \\
\hline Dry matter $(\mathrm{kg} / \mathrm{d})$ & $12 \cdot 5$ & $13 \cdot 6$ & $12 \cdot 2$ & $12 \cdot 3$ & 0.74 & NS & NS \\
\hline Nitrogen & 464 & 498 & 509 & 503 & $20 \cdot 74$ & NS & NS \\
\hline Ammonia & $16 \cdot 6$ & 17.9 & $14 \cdot 1$ & $16 \cdot 8$ & $1 \cdot 26$ & NS & NS \\
\hline Non- $\mathrm{NH}_{3}-\mathrm{N}$ & 447 & 478 & 495 & 487 & $20 \cdot 56$ & NS & NS \\
\hline Bacterial $\mathrm{N}$ & 179 & 188 & 202 & 199 & $9 \cdot 82$ & NS & $0 \cdot 15$ \\
\hline \multicolumn{8}{|l|}{ Amino acids } \\
\hline Arginine & 107 & 115 & 119 & 119 & $4 \cdot 88$ & NS & NS \\
\hline Histidine & 54 & 58 & 57 & 57 & $2 \cdot 03$ & NS & NS \\
\hline Isoleucine & 115 & 124 & 125 & 126 & $9 \cdot 84$ & NS & NS \\
\hline Leucine & 247 & 267 & 256 & 259 & $9 \cdot 84$ & NS & NS \\
\hline Lysine & 163 & 188 & 181 & 196 & $8 \cdot 06$ & 0.05 & NS \\
\hline Methionine & 44 & 49 & 47 & 50 & $2 \cdot 19$ & $0 \cdot 13$ & NS \\
\hline Phenylalanine & 120 & 129 & 128 & 131 & $4 \cdot 27$ & $\mathrm{NS}$ & NS \\
\hline Threonine & 116 & 124 & 126 & 127 & 4.67 & NS & NS \\
\hline Valine & 130 & 143 & 143 & 144 & $5 \cdot 18$ & NS & NS \\
\hline $\begin{array}{l}\text { Total essential } \\
\text { amino acids }\end{array}$ & 1098 & 1197 & 1183 & 1208 & $43 \cdot 2$ & NS & NS \\
\hline
\end{tabular}

NS, not significant $(P>0 \cdot 15)$.

* The interaction between AA and bST was not significant $(P>0.15)$.

$\dagger$ For details of treatments and procedures, see pp. 50-52.

were not contaminated. There was a tendency for the flow of bacterial $\mathrm{N}$ to be increased with bST $(P=0 \cdot 15)$. Duodenal flow measurements reported in Table 4 are exclusive of AA; however, lysine flow was increased $(P=0.05)$ and there was a tendency for methionine flow to increase $(P=0.13)$ with AA. This was probably due to retention of some of the infusate anterior to the cannula between sampling times.

\section{Plasma profiles}

bST increased the level of GH in plasma $(P=0.001)$ and AA increased plasma levels of lysine and methionine $(P<0.01$; Table 5). Urea-N levels were reduced $(P=0.06)$ in bSTtreated cows as were total EAA $(P=0.06)$. The urea cycle intermediates, citrulline, ornithine, and arginine also tended to be lower $(P<0 \cdot 15)$ for the bST treatments.

Ornithine and arginine, but not citrulline, were increased $(P<0.07)$ with AA. Histidine concentration was reduced in cows injected with bST, but not when bST-treated cows were also infused with amino acids, resulting in a significant interaction effect $(P=0.02)$.

\section{DISCUSSION}

The milk yield increase with bST administration was similar to the increase in other shortterm studies (Peel \& Bauman, 1987). The combination of amino acids plus bST did not increase milk yield or composition above that of bST alone, indicating that the production response to bST was not enhanced by providing additional lysine and methionine postruminally. These results are in agreement with those of Peel et al. (1982) who reported that 
Table 5. Plasma levels of growth hormone $(\mathrm{ng} / \mathrm{ml})$, urea $(\mathrm{mg} / \mathrm{l})$ and amino acids $(\mathrm{mg} / \mathrm{l})$ for cows given control $(C)$, duodenal infusion of methionine and lysine $(A A)$, injection of $b S T$ (bST), or the combination of $A A+b S T \dagger$

\begin{tabular}{|c|c|c|c|c|c|c|c|c|}
\hline \multirow[b]{2}{*}{ Treatment... } & \multirow[b]{2}{*}{$\mathrm{C}$} & \multirow[b]{2}{*}{ AA } & \multirow[b]{2}{*}{$\mathrm{bST}$} & \multirow[b]{2}{*}{$\mathrm{AA}+\mathrm{bST}$} & \multirow[b]{2}{*}{$\mathrm{SE}$} & \multicolumn{3}{|c|}{$\begin{array}{l}\text { Statistical significance } \\
(P=) \text { of effect of: }\end{array}$} \\
\hline & & & & & & $\mathrm{AA}$ & $\mathrm{bST}$ & $\mathrm{AA} \times \mathrm{bST}^{*}$ \\
\hline $\begin{array}{l}\text { Growth hormone } \\
(\mathrm{mg} / \mathrm{l})\end{array}$ & $2 \cdot 0$ & $1 \cdot 8$ & 34.9 & $31 \cdot 0$ & $5 \cdot 45$ & NS & 0.001 & NS \\
\hline $\begin{array}{l}\text { Urea-nitrogen } \\
(\mathrm{mg} / 1)\end{array}$ & 158 & 163 & 139 & 145 & $7 \cdot 9$ & NS & $0 \cdot 06$ & NS \\
\hline \multicolumn{9}{|c|}{ Amino acids ( $\mathrm{mg} / \mathrm{l})$} \\
\hline Arginine & $10 \cdot 1$ & $10 \cdot 8$ & $6 \cdot 2$ & $9 \cdot 1$ & $0 \cdot 7$ & 0.05 & 0.01 & NS \\
\hline Histidine & $4 \cdot 1$ & 4.0 & $2 \cdot 0$ & $4 \cdot 5$ & $0 \cdot 4$ & 0.03 & $0 \cdot 11$ & 0.02 \\
\hline Isoleucine & $14 \cdot 3$ & $12 \cdot 4$ & $9 \cdot 1$ & $13 \cdot 2$ & $1 \cdot 6$ & NS & NS & $0 \cdot 11$ \\
\hline Leucine & $19 \cdot 4$ & $16 \cdot 4$ & $12 \cdot 5$ & $17 \cdot 8$ & 1.8 & NS & NS & 0.06 \\
\hline Lysine & $8 \cdot 1$ & $13 \cdot 3$ & $5 \cdot 1$ & $12 \cdot 3$ & 1.6 & $0 \cdot 01$ & NS & NS \\
\hline Methionine & $3 \cdot 6$ & $4 \cdot 8$ & $2 \cdot 3$ & $4 \cdot 7$ & $0 \cdot 5$ & 0.01 & NS & NS \\
\hline Phenylalanine & $4 \cdot 9$ & 46 & 3.6 & 49 & $6 \cdot 0$ & NS & NS & NS \\
\hline Threonine & $8 \cdot 3$ & 8.7 & 6.8 & $4 \cdot 8$ & $1 \cdot 1$ & NS & 0.05 & NS \\
\hline Valine & $19 \cdot 4$ & $16 \cdot 8$ & $13 \cdot 0$ & $16 \cdot 3$ & 1.6 & NS & 0.07 & 0.12 \\
\hline $\begin{array}{l}\text { Total essential } \\
\text { amino acids }\end{array}$ & $92 \cdot 1$ & $91 \cdot 8$ & $60 \cdot 5$ & $87 \cdot 4$ & $7 \cdot 8$ & $0 \cdot 14$ & 0.06 & $0 \cdot 13$ \\
\hline Urea cycle & 28.9 & $30 \cdot 0$ & $21 \cdot 9$ & $27 \cdot 9$ & $2 \cdot 6$ & NS & 0.13 & NS \\
\hline
\end{tabular}

NS, not significant $(P>0 \cdot 15)$.

* Interaction between AA and bST.

$\uparrow$ For details of treatments and procedures, see pp. 50-52

\$ Citrulline + ornithine + arginine.

abomasal infusion of casein and glucose stimulated a small non-significant increase in milk and protein yields but, when combined with GH did not increase the response above the level achieved by $\mathrm{GH}$ alone. In a study completed while the current trial was in progress, Lynch et al. (1991) observed no additional milk production response to post-rumen lysine and methionine supplementation from cows injected with bST.

The most consistent response to post-rumen supplementation of lysine and methionine has been an increase in content or yield of milk protein (Schwab, 1989). Response to postrumen supplementation appears highly dependent on dietary protein level relative to requirements and the types of ingredients fed. The greatest responses have occurred in animals fed on low-protein diets in order to assess which amino acids were limiting (Schwab et al. 1976). Response to supplemental lysine and methionine has generally been greatest when a high proportion of the dietary protein was supplied by maize products (Schwab et al. 1976; Donkin et al. 1989) where lysine appeared to be the first limiting amino acid. In contrast, methionine supplementation of diets containing soya-bean products has improved lactational performance (Schingoethe et al. 1988). In the current trial calculated contributions to the total ration protein were: maize products (maize silage, maize grain, and maize gluten meal) $0 \cdot 47$, soybean meal $0 \cdot 46$, hay, molasses, and urea 0.07 , and with this distribution either lysine or methionine could have been limiting.

Milk protein or casein composition was not altered. This is in contrast to Donkin et al. (1989) who observed an increase in milk protein content, $\alpha$ - and $\beta$-casein and a decrease in $\mathrm{K}$-casein when mid-lactation cows were fed on protected methionine and lysine and a maize-based diet. The increase in the proportion of long-chain fatty acids in milk with bST 
injection is consistent with findings of Bitman et al. (1984), probably indicating that body stores of lipid were being mobilized to support the increase in milk production.

The intake of DM was not affected by either AA or bST. In short-term studies bST has been shown to have little effect on intake (Peel \& Bauman, 1987), but intake tends to increase in bST-treated cows after 46 weeks (Bauman et al. 1985). Positive responses to post-rumen administration of amino acids are partially accounted for by increases in feed intake (Schwab, 1989).

To assess the potential for either methionine or lysine to be limiting, the proportional flow of these two amino acids of the total EAA was calculated. Lysine constituted $0.15 \times$ EAA flow across treatments and methionine was 0.039 $\times$ EAA flow. Schwab (1989) reported that lysine was the first limiting amino acid for peak- and early-lactation cows when lysine flow was $0.13 \times$ EAA flow and methionine was second limiting or co-limiting when it constituted $0.039 \times$ EAA flow. In the studies cited (Schwab, 1989), lysine flow was similar $(175-185 \mathrm{~g} / \mathrm{d})$ but methionine flow was higher $(55-58 \mathrm{~g} / \mathrm{d})$ than in the present study. Thus, methionine may have been more limiting than lysine and this is consistent with other studies where soya-bean meal supplied a high proportion of the CP (Schingoethe et al. 1988).

Plasma urea concentrations were decreased in GH-treated mid-lactation cows but not in cows at peak lactation (McDowell et al. 1987). When measures of adipose tissue mobilization have been made simultaneously with some measure of amino acid oxidation in bST-treated animals there is a strong inverse relationship (Eisemann et al. 1986; McDowell et al. 1987) suggesting that lipid reserves are preferentially being oxidized, thus sparing amino acids for productive functions (Bauman \& McCutcheon, 1986). The greater ability of liver from bST-treated cows to convert propionate to glucose (Pocius \& Herbein, 1986) and a greater capacity to conserve glucose (De Boer \& Kennelly, 1989b) are other mechanisms whereby amino acids could be spared in bST-treated animals.

Since the ruminal supply of total EAA to the small intestine was similar across treatments, the decrease in EAA and branched-chain amino acid concentrations in plasma with bST treatment could have been due to their increased uptake by the mammary gland.

\section{Conclusions}

Providing $8 \mathrm{~g}$ methionine and $24 \mathrm{~g}$ lysine post-ruminally led to small increases in milk, fat, and protein yields. Injecting cows with bST stimulated larger increases in milk and component production but the response to bST was not enhanced by amino acids in cows producing an average an $34 \mathrm{~kg}$ milk. Duodenal nutrient flow was generally not affected by treatment. Plasma levels of urea- $\mathrm{N}$ and EAA and duodenal $\mathrm{NH}_{3}-\mathrm{N}$ levels were decreased with bST. A greater proportion of long-chain fatty acids in milk of bST-treated cows was probably indicative of mobilization of lipid reserves. This may have provided oxidative fuel for higher milk production and, thus, spared amino acids for other productive functions. Methionine appeared to be more limiting than lysine in this trial, and the production response to bST may have limited by methionine or other amino acids that became co-limiting. Further investigation is needed to determine if the long-term response to bST could be enhanced with additional amino acids.

The authors gratefully acknowledge Rhone Poulenc Co., Commentry, France, for major financial support and for plasma amino acid analyses. Agway Inc., Syracuse, NY provided partial funding and Lilly Research Laboratories, Greenfield, IN donated bST. They thank Dr Lester Griel, Dr Jack Kavanaugh, and Dr Robert Cloninger for surgical preparation of animals and veterinary care. For laboratory analysis, the assistance of Terri Whitsel was greatly appreciated. They thank Dr Elliot Block, McDonald College, Quebec, Canada for 
analysis of milk samples for protein fractions, Dr Barbara Glenn, USDA-ARS, BARC for design of the duodenal cannulas, and Dan Grunloh, University of Illinois for amino acid analysis. The authors thank D. R. Deaver and J. Peters for assaying plasma growth hormone.

\section{REFERENCES}

Association of Official Analytical Chemists (1980). Official Methods of Analysis, 12th ed. Washington, DC Association of Official Analytical Chemists.

Bauman, D. E., Eppard, P. J., DeGeeter, M. J. \& Lanza G. M. (1985). Responses of high producing dairy cows to long-term treatment with pituitary somatotropin and recombinant somatotropin. Journal of Dairy Science 68, 1352-1362.

Bauman, D. E. \& McCutcheon, S. N. (1986). The effects of growth hormone and prolactin on metabolism. In Control of Digestion and Metabolism in Ruminants, pp. 436-455 [L. D. Milligan, W. L. Grovum, and A. Dobson, editors]. New Jersey: Prentice Hall.

Bitman, J., Wood, D. L., Tyrrell, H. F., Bauman, D. E., Peel, C. J., Brown, A. C. G. \& Reynolds, P. J. (1984). Blood and milk lipid responses induced by growth hormone administration in lactating cows. Journal of Dairy Science 67, $2873 \cdot 2880$.

Botts, R. L., Hemken, R. W. \& Bull, L. S. (1979). Protein reserves in lactating dairy cow. Journal of Dairy Science 62, 433-440.

Chaney, A. L. \& Marbach, E. P. (1962). Modified reagents for determination of urea and ammonia. Clinical Chemistry 8, 130-132.

Christopherson, S. W. \& Glass, R. L (1969). Preparation of milk fat methyl esters by alcoholysis in an essential nonalcoholic solution. Journal of Dairy Science 52, 1289-1290.

De Boer, G. \& Kennelly, J. J. (1989a). Effect of somatotropin injection and dietary protein concentration on milk yield, and kinetics of hormones in dairy cows. Journal of Dairy Science 66, 419-428.

De Boer, G. \& Kennelly, J. J. $(1989 b)$. Effect of somatotropin and dietary protein concentration on hormone and metabolite responses to single injections of hormones and glucose. Journal of Dairy Science 72, $429 \mathbf{4 3 5}$.

Donkin, S. S., Varga, G. A., Sweeney, T. F. \& Muller, L. D. (1989). Rumen-protected methionine and lysine: effects on animal performance, milk protein yield, and physiological measures. Journal of Dairy Science $\mathbf{7 2}$, 1484-1491.

Eisemann, J. H., Hammond, A. C., Bauman, D. E., Reynolds, P. J., McCutcheon, S. N., Tyrrell, H. F. \& Haaland, G. L. (1986). Effect of bovine growth hormone administration on metabolism of growing Hereford heifers: protein and lipid metabolism and plasma concentrations of metabolites and hormones. Journal of Nutrition 116, 2504-2515.

Glenn, B. P., Varga, G. A., Huntington, G. B. \& Waldo, D. R. (1989). Duodenal nutrient flow and digestibility in Holstein steers fed formaldehyde- and formic acid-treated alfalfa or orchardgrass silage at two intakes. Journal of Animal Science 67, 513-528.

Hart, S.P. \& Polan, C. E. (1984). Simultaneous extraction and determination of ytterbium and cobalt ethylenediaminetetraacetate complex in feces. Journal of Dairy Science 67, 888-892.

Lormore, M. J., Muller, L. D., Deaver, D. R. \& Griel, L. C. Jr (1990). Early lactation responses of dairy cows administered bovine somatotropin and fed diets high in energy and protein. Journal of Dairy Science 73, 3237-3247.

Lynch, G. L., Klusmeyer, T. H., Cameron, M. R., Clark, J. H. \& D. R. Nelson. (1991). Effects of somatotropin and duodenal infusion of amino acids on nutrient passage to duodenum and performance of dairy cows. Journal of Dairy Science 74, 3117-3127.

McDowell, G. H., Hart, I. C., Bines, J. A., Lindsay, D. B. \& Kirby, A. C. (1987). Effects of pituitary-derived bovine growth hormone on production parameters and biokinetics of key metabolites in lactating cows at peak and mid-lactation. Australian Journal of Biological Science 40, 191-202.

McGuffey, R. K., Green, H. B. \& Basson, R. P. (1990). Lactation response of dairy cows receiving bovine somatotropin and fed rations varying in crude protein and undegradable intake protein. Journal of Dairy Science 73, 2437-2443.

National Research Council (1985). Ruminant Nitrogen Usage. Washinton, DC: National Academy Press.

National Research Council (1989). Nutrient Requirements of Dairy Cattle, 6th revised ed. Washington, DC: National Academy Press.

Ng-Kwai-Hang, K. F. \& Kroeker, E. M. (1984). Rapid separation and quantification of major casein and whey proteins of bovine milk by polyacrylamide gel electrophoresis. Journal of Dairy Science 67, 3052-3056

Peel, C. J. \& Bauman, D. E. (1987). Somatotropin and lactation. Journal of Dairy Science 70, 474-486.

Peel, C. J., Bauman, D. E., Gorewit, R. C. \& Sniffen, C. J. (1981). Effect of exogenous growth hormone on lactational performance in high yielding dairy cows. Journal of Nutrition 111, 1662-1671.

Peel, C. J., Fronk, T. J., Bauman, D. E. \& Gorewit, R. C. (1982). Lactational response to exogenous growth hormone and abomasal infusion of a glucose-sodium caseinate mixture in high yielding dairy cows. Journal of Nutrition 112, 1770-1778. 
Pocius, P. A. \& Herbein, J. H. (1986). Effects of in vivo administration of growth hormone on milk production and in vitro hepatic metabolism in dairy cattle. Journal of Dairy Science 69, 713-720.

Robertson, J. B. \& Van Soest, P. J. (1981). The detergent system of analysis and its application to human foods. In The Analysis of Dietary Fiber in Food, pp. 123-155 [W. P. James and O. Theander, editors]. New York: Marcel Dekker Inc.

SAS Institute Inc. (1985). SAS User's Guide: Statistics. Cary, North Carolina: SAS Institute Inc.

Schingoethe, D. J., Casper, D. P., Yang, C., Illg, D. J., Sommerfeldt, J. L. \& Mueller, C. R. (1988). Lactational responses to soybean meal, heated soybean meal, and extruded soybeans with ruminally protected methionine. Journal of Dairy Science 71, 173-180.

Schwab, C. G. (1989). Amino acids in dairy cow nutrition. Rhone-Poulenc Technical Symposium, pp. 75-101. Fresno: California Nutrition Conference.

Schwab C. G., Satter, L. D. \& Clay, A. B. (1976). Response of lactating cows to abomasal infusion of amino acids. Journal of Dairy Science 59, 1254-1270.

Tyrrell, H. F., Brown, A. C. G., Reynolds, P. J., Haaland, G. L., Bauman, D. E., Peel, C. J. \& Steinhour, W. D. (1988). Effect of bovine somatotropin on metabolism of lactating dairy cows: energy and nitrogen utilization as determined by respiration calorimetry. Journal of Nutrition 118, 1024-1030.

Varga, G. A., Hoover, W. H., Junkins, L. L. \& Shriver, B. J. (1988). Effects of urea and isoacids on in-vitro fermentation of diets containing formaldehyde-treated or untreated soybean meal. Journal of Dairy Science 71, 737-744.

Wanderley, R. C., Al Dehneh, A., Huber, J. T., Theurer, C. B., \& Teixeira, J. C. (1988). Duodenal amino acid supply in dairy cows. Journal of Animal Science 66, Suppl. 1, 484.

Winsryg, M. D., Arambel, M. J. \& Walters, J. L. (1991). The effect of protein degradability on milk composition and production of early lactation, somatotropin-injected cows. Journal of Dairy Science 73, 2437-2443.

Zinn, R. A. \& Owens, F. N. (1986). A rapid procedure for purine measurement and its use for estimating net ruminal protein synthesis. Canadian Journal of Animal Science 66, 157-166. 